\title{
Autologous blood derived cell therapy in maxillofacial bone graft surgery
}

\author{
Joo-Young Park \\ Department of Oral and Maxillofacial Surgery, Seoul National University Dental Hospital, \\ School of Dentistry, Seoul National University, Seoul, Korea
}

\begin{abstract}
J Korean Assoc Oral Maxillofac Surg 2021;47:480-483)
Tissue regeneration is one of the ultimate goals of maxillofacial surgery and various types of tissue engineering technologies have been utilized in clinics. Healthy resources of host cells and growth factors are essential for the tissue engineering, therefore autologous blood-derived cell therapy was introduced. In this article, clinical applications of the autologous platelet concentrates and stem cell separation therapy will be summarized and evaluated for their efficacy and feasibility in the current maxillofacial clinics.
\end{abstract}

Key words: Tissue engineering, Regeneration, Maxilla, Mandible, Autografts

[paper submitted 2021. 6. 30 / accepted 2021. 7. 8]

\section{Introduction}

Bone graft in maxillofacial field is a procedure performed to increase the amount of alveolar or basal jaw bones where they have been lost by diseases, trauma, or surgeries. Because of the difficulties to regenerate the bony defects completely and rapidly, various types of tissue engineering technologies have been applied in maxillofacial clinics ${ }^{1-4}$. For example, bone graft materials such as allogenic, xenogeneic, and synthetic bones were introduced and used as scaffolds, as well as barrier membranes and titanium mesh are available to facilitate proper three-dimensional (3D) shapes of bone formation. Importantly, one of the missing aspects in this endeavor is lack of healthy resources of host cells and growth factors, such as local mesenchymal stem cells or bone marrow progenitor cells with autologous growth factors. To overcome this limitation, autologous blood-derived cell therapy was introduced several decades ago consisting of platelet concen-

\footnotetext{
Joo-Young Park

Department of Oral and Maxillofacial Surgery, Seoul National University Dental Hospital, School of Dentistry, Seoul National University, 101 Daehak-ro, Jongno-gu, Seoul 03080, Korea

TEL: +82-2-2072-4498

E-mail:bbyoung1@snu.ac.kr

ORCID: https://orcid.org/0000-0002-0333-6349
}

(c) This is an open-access article distributed under the terms of the Creative Commons Attribution Non-Commercial License (http://creativecommons.org/ licenses/by-nc/4.0/), which permits unrestricted non-commercial use, distribution, and reproduction in any medium, provided the original work is properly cited.

Copyright (C) 2021 The Korean Association of Oral and Maxillofacial Surgeons. trates (PCs) such as platelet-rich plasma (PRP) and plateletrich fibrin (PRF). In addition to the PCs, closed system of stem cell separation from the patients' own bone marrow or blood was also developed and utilized in clinics. In this article, clinical applications of the autologous blood derived cell therapy will be summarized and evaluated for their efficacy and feasibility in maxillofacial surgery.

\section{Types of Clinically Available Autologous Blood Derived Cell Therapy}

\section{Platelet-rich plasma}

The concept of PCs was originated from the idea that platelets and autologous growth factors could be condensed in plasma and utilized to promote local wound healing. The first generation of PCs was given the popular name PRP and is composed of over $95 \%$ platelets, a cell type that actively secretes growth factors for initiating wound healing and secreting factors responsible for enhancing cell adhesion, proliferation, and migration of various cell types ${ }^{6-8}$. However, PRP preparation requires addition of bovine thrombin or $\mathrm{CaCl}_{2}$ which makes that PRP is not $100 \%$ autologous. Furthermore, the preparation must be centrifuged in two separate stages to increase purity of platelet concentration.(Fig. 1, 
left) It has further been reported that the liquid nature of PRP complicates its handling by clinicians. All these limitations have led to the emergence of a second-generation PCs.

\section{Platelet-rich fibrin}

PRF can be fabricated from 100\% autologous sources without any bovine thrombin or $\mathrm{CaCl}_{2}$ and can be fabricated by a one-step standardized method ${ }^{9-11}$. Through centrifugation of peripheral blood, physiologic clot formation and fractioning are induced. The natural clot formation by centrifugation requires using specific tubes with a glass surface initiates the coagulation cascade and activates platelets during centrifugation. The resulting PRF consists of a fibrin scaffold that contains platelets, leukocytes, and plasma proteins. After centrifugation, the resulted 3D fibrin matrix of the PRF serves as a reservoir of growth factors and soft tissue barriers.(Fig. 1, middle)

\section{Closed cell separation system for autologous bone marrow or whole blood}

Efforts to separate blood cells, especially hematopoietic stem cells from patients' own blood have been made to utilize the stem cell fractions for tissue engineering. There are a multitude of ways to sort different types of cell components and one of the quicker ways to sort a sample based on physical characteristics is density gradient centrifugation. However, the first trial to separate and transplant the autologous human bone marrow mononuclear cells was only conducted in 2001 for treatment of chronic heart disease and peripheral arterial disease using SEPAX system ${ }^{12}$. Several companies developed commercially available closed centrifugation system to efficiently separate blood cell fractions aseptically to maintain the high standards required for cellular therapeutics ${ }^{13-15}$. (Fig. 1, right) Although transplantation of the stem cell fraction is efficient for tissue regeneration, statistics and official report from the Korean Ministry of Health and Welfare in 2018 showed that only 4 autologous or allogenic stem cell products have been approved and available in clinics among all 15 cell therapy products in South Korea. However, not a single cell therapy product is approved yet for dentistry and maxillofacial surgery field.

\section{Controversies in Usage of Autologous Blood Derived Cell Therapy in Maxillofacial Surgery}

\section{Advantages}

Numerous studies on PRP and PRF were published to show efficacy for their dental tissue regeneration, such as regeneration of periodontal bony defect, tooth furcation defect, gingival defect on tooth roots, extraction socket preservation and maxillary sinus membrane elevation ${ }^{8-11,16}$. Autologous

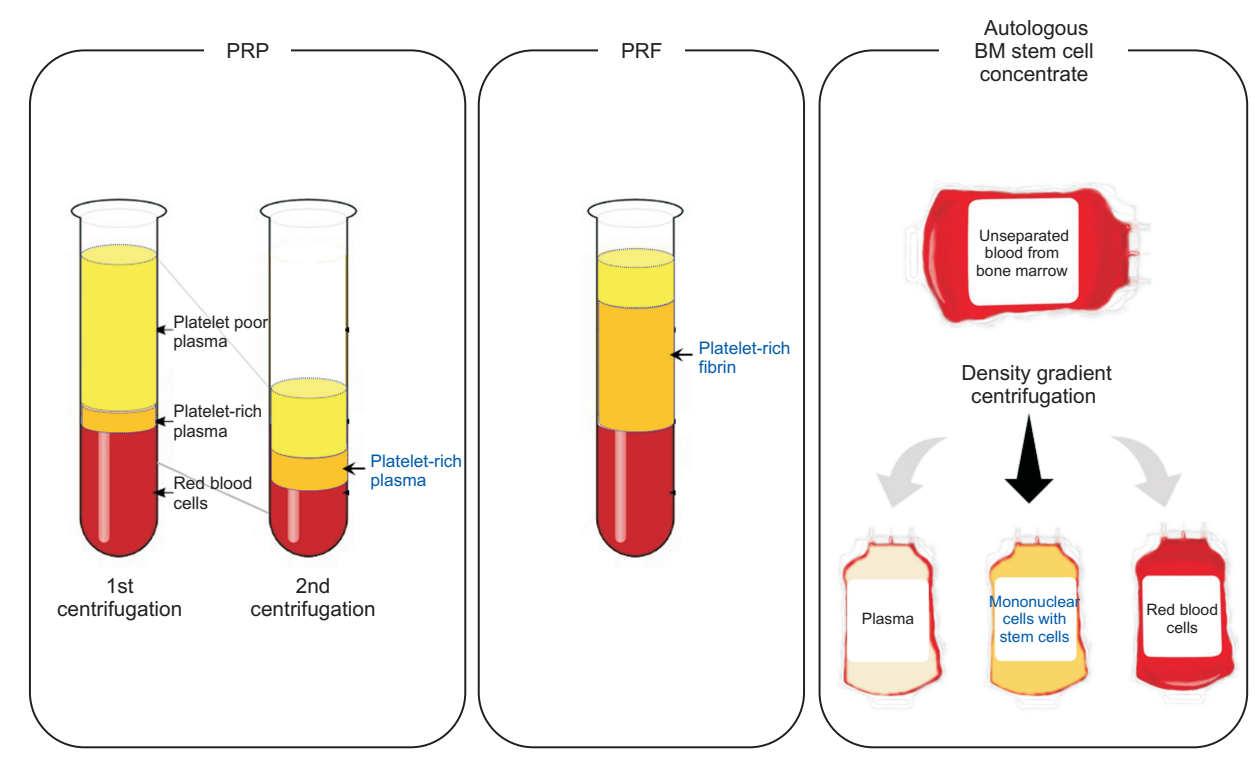

Fig. 1. The layers after centrifugation, the blood components and separated cells are shown among PRP (platelet-rich plasma; the most left), PRF (platelet-rich fibrin; middle) and autologous bone marrow (BM) stem cell concentrate (the most right). The final product from each preparation method is written in blue.

Joo-Young Park: Autologous blood derived cell therapy in maxillofacial bone graft surgery. J Korean Assoc Oral Maxillofac Surg 2021 
stem cells separated from blood or bone marrow also have been showed superior soft tissue wound healing in dermatology, cardiology, and plastic surgery ${ }^{12-15}$. Furthermore, recent studies showed that platelets and mesenchymal stem cells promote tissue regeneration by modulating local immune reactions $^{17,18}$.

\section{Disadvantages}

Autologous blood-derived cell products require manipulation procedures ex vivo, so that there has been contamination, safety, and standardization issues for clinical application. Additionally, health technology assessment was first introduced in South Korea in 2006, and the Committee of New Health Technology Assessment (CNHTA) was formed and started to review safety and effectiveness of the new health technology. Since then, PCs in various medical applications tried to be approved as a new medical technology by CNHTA; however, no trial was succeeded until January 2019. Currently, autologous PRP application is approved for single usage in treatment of tennis elbow; Epicondylopathia humeri radialis, and no other medical, dental, and maxillofacial usage is approved.

\section{Summary and Editor's Opinion}

(1) Autologous blood-derived cell therapy can supply healthy resources of host cells and growth factors to promote tissue regeneration in maxillofacial surgery field.

(2) Although there have been controversies in efficacy and feasibility of PCs and stem cell transplantation, the autologous blood-derived cell therapy is one of the better options for regeneration of maxillofacial tissues.

(3) We need more in vivo and clinical trial data to find the proper therapeutic doses for autologous PCs and stem cells suitable for different clinical situations in maxillofacial surgery.

(4) Development of concrete and practical solutions including standardized clinical protocols, technologies and delivery systems of PCs and stem cell fractions will become essential in the future.

\section{Author's Contributions}

The manuscript was written by J.Y.P.

\section{Conflict of Interest}

No potential conflict of interest relevant to this article was reported.

\section{References}

1. Ceccarelli G, Presta R, Benedetti L, Cusella De Angelis MG, Lupi SM, Rodriguez Y Baena R. Emerging perspectives in scaffold for tissue engineering in oral surgery. Stem Cells Int 2017;2017: 4585401. https://doi.org/10.1155/2017/4585401

2. Doonquah L, Holmes PJ, Ranganathan LK, Robertson H. Bone grafting for implant surgery. Oral Maxillofac Surg Clin North Am 2021;33:211-29. https://doi.org/10.1016/j.coms.2021.01.006

3. Rakhmatia YD, Ayukawa Y, Furuhashi A, Koyano K. Current barrier membranes: titanium mesh and other membranes for guided bone regeneration in dental applications. J Prosthodont Res 2013; 57:3-14. https://doi.org/10.1016/j.jpor.2012.12.001

4. Zhao R, Yang R, Cooper PR, Khurshid Z, Shavandi A, Ratnayake J. Bone grafts and substitutes in dentistry: a review of current trends and developments. Molecules 2021;26:3007. https://doi. org/10.3390/molecules 26103007

5. Masoudi E, Ribas J, Kaushik G, Leijten J, Khademhosseini A. Platelet-rich blood derivatives for stem cell-based tissue engineering and regeneration. Curr Stem Cell Rep 2016;2:33-42. https:// doi.org/10.1007/s40778-016-0034-8

6. Marx RE. Platelet-rich plasma: evidence to support its use. J Oral Maxillofac Surg 2004;62:489-96. https://doi.org/10.1016/ j.joms.2003.12.003

7. Marx RE, Carlson ER, Eichstaedt RM, Schimmele SR, Strauss JE, Georgeff KR. Platelet-rich plasma: growth factor enhancement for bone grafts. Oral Surg Oral Med Oral Pathol Oral Radiol Endod 1998;85:638-46. https://doi.org/10.1016/s1079-2104(98)90029-4

8. Xu J, Gou L, Zhang P, Li H, Qiu S. Platelet-rich plasma and regenerative dentistry. Aust Dent J 2020;65:131-42. https://doi. org/10.1111/adj.12754

9. Miron RJ, Fujioka-Kobayashi M, Bishara M, Zhang Y, Hernandez M, Choukroun J. Platelet-rich fibrin and soft tissue wound healing: a systematic review. Tissue Eng Part B Rev 2017;23:83-99. https:// doi.org/10.1089/ten.TEB.2016.0233

10. Miron RJ, Zucchelli G, Pikos MA, Salama M, Lee S, Guillemette $\mathrm{V}$, et al. Use of platelet-rich fibrin in regenerative dentistry: a systematic review. Clin Oral Investig 2017;21:1913-27. https://doi. org/10.1007/s00784-017-2133-Z

11. Naik B, Karunakar P, Jayadev M, Marshal VR. Role of platelet rich fibrin in wound healing: a critical review. J Conserv Dent 2013;16: 284-93. https://doi.org/10.4103/0972-0707.114344

12. Strauer BE, Brehm M, Zeus T, Gattermann N, Hernandez A, Sorg $\mathrm{RV}$, et al. [Intracoronary, human autologous stem cell transplantation for myocardial regeneration following myocardial infarction]. Dtsch Med Wochenschr 2001;126:932-8. German. https://doi. org $/ 10.1055 / \mathrm{s}-2001-16579-2$

13. Aktas M, Radke TF, Strauer BE, Wernet P, Kogler G. Separation of adult bone marrow mononuclear cells using the automated closed separation system Sepax. Cytotherapy 2008;10:203-11. https://doi. org/10.1080/14653240701851324

14. Güven S, Karagianni M, Schwalbe M, Schreiner S, Farhadi J, Bula $\mathrm{S}$, et al. Validation of an automated procedure to isolate human adipose tissue-derived cells by using the Sepax ${ }^{\circledR}$ technology. Tissue Eng Part C Methods 2012;18:575-82. https://doi.org/10.1089/ten. TEC.2011.0617

15. Mazzanti B, Urbani S, Dal Pozzo S, Bufano P, Ballerini L, Gelli A, et al. Fully automated, clinical-grade bone marrow processing: a 
single-centre experience. Blood Transfus 2017;15:577-84. https:// doi.org/10.2450/2016.0057-16

16. Kobayashi E, Flückiger L, Fujioka-Kobayashi M, Sawada K, Sculean A, Schaller B, et al. Comparative release of growth factors from PRP, PRF, and advanced-PRF. Clin Oral Investig 2016;20: 2353-60. https://doi.org/10.1007/s00784-016-1719-1

17. Cruz-Barrera M, Flórez-Zapata N, Lemus-Diaz N, Medina C, Galindo CC, González-Acero LX, et al. Integrated analysis of transcriptome and secretome from umbilical cord mesenchymal stromal cells reveal new mechanisms for the modulation of inflammation and immune activation. Front Immunol 2020;11:575488. https://doi.org/10.3389/fimmu.2020.575488
18. Li C, Li J, Li Y, Lang S, Yougbare I, Zhu G, et al. Crosstalk between platelets and the immune system: old systems with new discoveries. Adv Hematol 2012;2012:384685. https://doi. org $/ 10.1155 / 2012 / 384685$

How to cite this article: Park JY. Autologous blood derived cell therapy in maxillofacial bone graft surgery. J Korean Assoc Oral Maxillofac Surg 2021;47:480-483. https://doi.org/10.5125/ jkaoms.2021.47.6.480 